DOI https://doi.org/10.18551/rjoas.2018-10.33

\title{
THE EFFECT OF DIALOGIC COMMUNICATION IN SAFE TRAVEL APPLICATION ON DIGITAL DIPLOMACY OF THE MINISTRY OF FOREIGN AFFAIRS OF THE REPUBLIC OF INDONESIA
}

\author{
Suharyanti*, Andika M. Tri, Pamungkas Bani, Badaruddin Muhammad \\ Faculty of Economics and Social Sciences, University of Bakrie, Jakarta, Indonesia \\ *E-mail: suharyanti@bakrie.ac.id
}

\begin{abstract}
Along with the development of information and communication technology and the implementation of strategic objectives, the Ministry of Foreign Affairs of the Republic of Indonesia (KEMLU RI) applies digital diplomacy using Safe Travel which involves dialogic communication within it. This research was conducted to analyze the influence of dialogic communication from Safe Travel on digital diplomacy conducted by KEMLU RI. This study used a mix-method approach with data collected through surveys and interviews, then analyzed by a multiple linear regression. The results of the study with 42 respondents from the students of Bakrie University Communication Study Program showed that dialogic communication does not fully affect digital diplomacy. Among the five dimensions of dialogic communication, only dialogic loops and generation of return visits have a positive effect on digital diplomacy while the usefulness of information, the usability interface, and visitor conservation have no effect.
\end{abstract}

\section{KEY WORDS}

Communications, dialogic communications, safe travel, digital diplomacy.

The trend for Indonesian citizen (WNI) to travel abroad in 2018 is predicted to increase. It can be indicated from the increase in the number of Indonesian citizens going abroad from 8.4 million people in 2016 to 9.1 million people in 2017 (Kompas.com, accessed on August $14,2018)$. The main factor of this trend is the change in Indonesian people's behavior due to the presence of cheap travel packages (Kompas.com, accessed on August 14, 2018). Another factor is the people's desire to make a pilgrimage to Mecca and work abroad as Indonesian Migrant Workers (TKI).

This trend cannot be seen as an ordinary phenomenon. All parties, particularly the government, must notice several aspects, one of which is the security issue for Indonesian tourists in foreign countries. Information about the security is highly important for those who will travel abroad.

Informing and monitoring the security of Indonesian tourists overseas is not easy because of limited distances and time differences. Conventional media is no longer able to reach the community due to these limitations. However, the presence of the internet provides solutions to these problems.

Entering the 2000s, the internet grew rapidly in Indonesia. In 2017, the survey results of the Indonesian Internet Service Providers Association showed an internet user penetration of $54.68 \%$ or 143.26 people of the total Indonesia population (Surabaya.tribunnews.com, accessed on August 14, 2018).

Not only done conventionally, but some of the Indonesian people's activities have also currently been influenced by the internet. Many digital applications emerge to facilitate and fulfil people's needs, such as shopping and transportation. To monitor the Indonesian tourist trend and the rapid number of internet users, the Ministry of Foreign Affairs of the Republic of Indonesia (KEMLU RI) utilizes digital developments to overcome problems likely to be faced by Indonesian citizens abroad.

In line with the strategic steps and focus of Indonesia's foreign politics, KEMLU RI runs its strategies of digital diplomacy. Digital diplomacy is a new concept of public diplomacy involving the use of digital technology and social media to communicate with foreigners 
(Adesina, 2017: 1). KEMLU RI has much used digital media to carry out its digital diplomacy strategies, including website and social media (Twitter, Facebook, and Instagram). In the early of 2018, KEMLU RI designed again new innovations in realizing digital diplomacy, namely Safe Travel application. Safe Travel is a digital-based application created as a tool to improve the protection of Indonesian citizens travelling abroad (KEMLU, 2018: 15). As a public diplomacy tool, Safe Travel allows for indirect communication between Indonesian citizens and KEMLU RI parties.

According to Ruben and Stewart (2006: 15), communication is the bridge between individuals and the world, where we study about ourselves and others. The need to socialize is one of the factors driving the rapid change in communication patterns and media. This combination of communication and the internet is often called digital communication. Indirect communication through Safe Travel application brings up dialogues between users and the system. In the practice of communication, dialogues emerging in the digital world are called dialogic communication.

According to Kent and Tylor (1998 and 2002, in Agozzino, 2015: 4), dialogic communication is one approach to build relationship between organizations and the public online in which there is an exchange of ideas and opinions communicatively allowing both parties involved to understand each other and continue to exchange information until both parties are satisfied.

From the above description, the researchers formulated the following statements of problems:

- How does dialogic communication of Safe Travel application affect digital diplomacy conducted by KEMLU RI?

- Are there similarities or differences in communication strategy understanding between media users (public) and KEMLU RI on the presence of Safe Travel application?

Based on the statements of problems above, the objective of this research was to analyze the effect resulted from the dialogic communication in Safe Travel application on the digital diplomacy of Indonesia's Ministry of Foreign Affairs.

\section{LITERATURE REVIEW}

Public Diplomacy. According to Cohen (1998, in Adesina, 2017: 2), a diplomacy is a machine of international relations which becomes a method for countries to articulate their foreign policy objectives, coordinate their efforts to influence decisions and behavior of foreign governments and communities through dialogues and negotiations.

Public diplomacy has been defined as a country's soft power, marketing and branding as well as international public relations by the government (Zhang, 2013: 1314).

As the main difference, traditional diplomacy has traditional approaches based on government-to-government relations while public diplomacy builds relations between governments and foreign publics (Seib, 2009: 773).

Digital Diplomation as a New Form of Public Diplomacy. Adesina (2017: 2) described that in the modern era, public diplomacy has changed mainly due to Technology, Information and Communication (TIC). TIC has revolutionized the way people communicate and exchange information and change the political, social and economic landscapes around the world.

Digital diplomacy refers to diplomatic practices through digital technology and networks, including the internet, mobile devices, and social media channels (Potter, 2002, in Adesina, 2017: 3).

Moreover, Hanson (2012, in Adesina, 2017: 3) explains that there are eight objectives of digital diplomacy, covering:

- Knowledge Management. Utilizing knowledge of a department and government so as to be maintained, shared and used optimally to pursue national interests abroad. 
- Public Diplomacy. Making contact with audiences when they migrate online by utilizing new communication tools to listen to and target important audiences to deliver messages and affect influencers online.

- Information Management. Helping gather information flows to support policy making as well as anticipate and respond to emerging social and political movements.

- Consular Communications and Response. Making direct communication channels with citizens travelling abroad, which can be managed in crisis situations.

- Disaster Response. Utilizing the power of communication technology in responding to a disaster.

- Internet Freedom. Creating technology to maintain free and open internet. This is related to the aim of promoting freedom of speech and democracy and weakening the authoritarian regime.

- External Resources. Creating a digital mechanism to approach and utilize external skills to advance national goals.

- Policy Planning. Enabling effective oversight and international policy coordination and planning throughout the government in response to bureaucratic internationalization.

Communication. Communication is a processing system in which humans engage and interact using symbols to create and interpret a meaning (Wood, 2011: 12).

According to Effendy (2013: 27), there are four functions of communication, namely:

- To change the attitude, referring to changes in individual or group attitudes due to the acceptance of information;

- To change opinion, referring to changes in individual or group opinions due to information received;

- To change the behavior, referring to changes in individual or group behavior towards something due to the acceptance of information;

- To change society, referring to changes in the social level of individuals or groups due to the acceptance of information.

Dialogic Communication as a Strategic Framework for Web-Based Relations. According to Kent and Taylor (2014, in Anderson, Swenson, and Gillkerson, 2016), a dialogue is an orientation that values the sense of sharing and understanding between parties that interact.

Dialogic communication is one of the well-known approaches to Public Relations (PR) practitioners in building relationships between organizations and the public, developed by Pearson in 1998 and extended by Kent and Taylor in 1998 to 2002 (McAllister-Spooner, 2008: 2).

Dialogic communication is an ethical approach arising due to open communication that demands cooperation and negotiation to build a relationship with the public (Pearson, 1998, in Agozzino, 2015: 4). According to Kent and Taylor (1998, in Agozzino, 2015: 4), dialogic communication can facilitate relationships between organizations and the public established by online media.

In building a relationship, Kent and Taylor (1998, in Kampf, Manor, Segev, 2015) suggested five basic principles of dialogic communication as follows:

- Dialogic loops. Focusing on public opportunities to ask questions to organizations and organizations' opportunity to answer it.

- Usefulness of information. Obtaining information from sources that are reliable, useful and relevant to the public.

- Generation of return visits. Focusing on continually updating information, adjusting information to public needs, and holding a Q\&A forum with experts.

- The interface usability. Preferring easy and textual navigation to online graphics contents

- Conservation of visitors. Avoiding publications that encourage the public not to give feedback or make another visit.

New Media. New media refers to large-scale changes in the production, distribution, and use of media that are technological, textual, conventional, and cultural (Lister et al., 
2009: 13). According to McQuail (2011: 43), new media has main characteristics such as the existence of connections, the facility to send and receive messages and have interactive and open communication at any time and anywhere.

Safe Travel as a Media in the Digital Era. Quoted from the official site of KEMLU RI (www.kemlu.go.id, accessed on August 15, 2018), Safe Travel is one of the digital media utilized by Indonesia's Ministry of Foreign Affairs to protect Indonesian citizens in foreign countries.

Starting from the site www.peduliwni.kemlu.go.id, KEMLU RI expands the mobile application 'Safe Travel Kemlu' that was launched in 2017 to be multi-platform (Android, iOS, web, and social media). Both applications were introduced in April 2018.

The features provided by Safe Travel consist of:

- Complete Information on World Countries. Containing information about the country status, access to RI Representative services, list of 130 RI Representatives, local laws and customs, currency, tourism and worship objects, halal culinary, and infographics.

- Emergency Button. In emergency situations, Indonesian citizens in foreign countries can use the Emergency Button feature to send photos, record videos, contact the nearest RI Representative and send important scenes.

- Indonesia Nearby. This feature provides information about other Indonesian citizens nearby the user's location when travelling abroad. With this feature, Indonesian citizens can each other get acquainted, chat and develop a network of friends to strengthen the community of Indonesian citizens abroad.

- Points and Badges. The application users can also get points and badges after logging in. There will be a reward for those who get certain points and badges.

Users of this Safe Travel application can display their selfie photos and log in to upload or share it to social media such as Facebook so they can still exist with cyberspace friends.

Hypothesis. Based on the literature review above, the researchers then proposed the following hypotheses:

$\mathrm{H1}$ : Dialogic loop has a positive effect on digital diplomacy.

H2: Usefulness of information has a positive effect on digital diplomacy.

H3: Generation of return visits has a positive effect on digital diplomacy.

H4: The interface usability has a positive effect on digital diplomacy.

$\mathrm{H} 5$ : Conservation of visitors has a positive effect on digital diplomacy.

\section{METHODS OF RESEARCH}

This research used the post-positivistic paradigm. According to Creswell (2008, in Hesse-Biber and Leavy, 2011: 16), post-positivistic is similar to positivistic. The difference is when researchers cannot really be positive about their knowledge claims at the time of studying social reality. The post-positivistic paradigm tries to make evidence that will confirm or refute a theory even though not in absolute terms (Hesse-Biber and Leavy, 2011: 16).

Based on the research objectives to be achieved, this research used a mix-method approach. According to Sugiyono (2014: 18), a mixed method is an approach that combines quantitative and qualitative methods in one study so as to obtain comprehensive, valid, reliable, and objective data. In this research, the alternative mix method strategy used was a sequential explanatory strategy. A sequential explanatory strategy is a strategy used in mixmethod research with a tendency to a quantitative approach. Sequential explanatory strategy characteristics can be seen when data are collected and analyzed quantitatively in the initial phase, then the quantitative data results are followed by data collection and analysis done qualitatively in the second phase (Creswell, 2008: 2011).

. The data were collected using surveys and interviews. A survey is a data collection technique in which researchers and data collectors ask questions and propose statements to respondents, both in oral and written forms (Sanusi, 2011: 103). Meanwhile, an interview is a data collection technique presented in a structured, unstructured and semi-structured forms consisting of several open questions related to the topic of research (Hancock et al., 2009: 
16). In this research, interviews were used to collect additional data to support the questionnaire results.

The object of this research was Bakrie University's students. The population of this research was all the students of the Communication Study Program at Bakrie University. The sampling was conducted purposively. According to Sugiyono (2014: 126), purposive sampling is done in research to take subjects based on the existence of certain objectives.

This research deliberately took students representing the younger generation who had travelled abroad. The sample determination was based on the fact that $K E M L U R I$ targets Millennial and $Z$ generations as Safe Travel application users (Kumparan.com, accessed on September 9, 2018). Millennial and $Z$ generations are people born in the internet generation - a generation who has enjoyed the magic of technology after the internet emergence (Tirto.id, accessed on September 2019) in which they understand enough the use of internet media including travel applications such as Safe Travel.

The data were collected using systematic and structured arranged questionnaires. The questionnaires used a 5 point-Likert scale measurement, covering Very Agree, Agree, Less Agree, Disagree, and Very Disagree. The use of odd interval scale aims to see the tendency of respondents to choose a middle scale.

Variables in this research were divided into two types, namely independent and dependent variables. Independent variable is a variable affecting or occurring due to changes or the emergence of the dependent variable (Sugiyono, 2014: 59). Meanwhile, a dependent variable is a variable affected by or resulted from the independent variable (Sugiyono, 2014: 59).

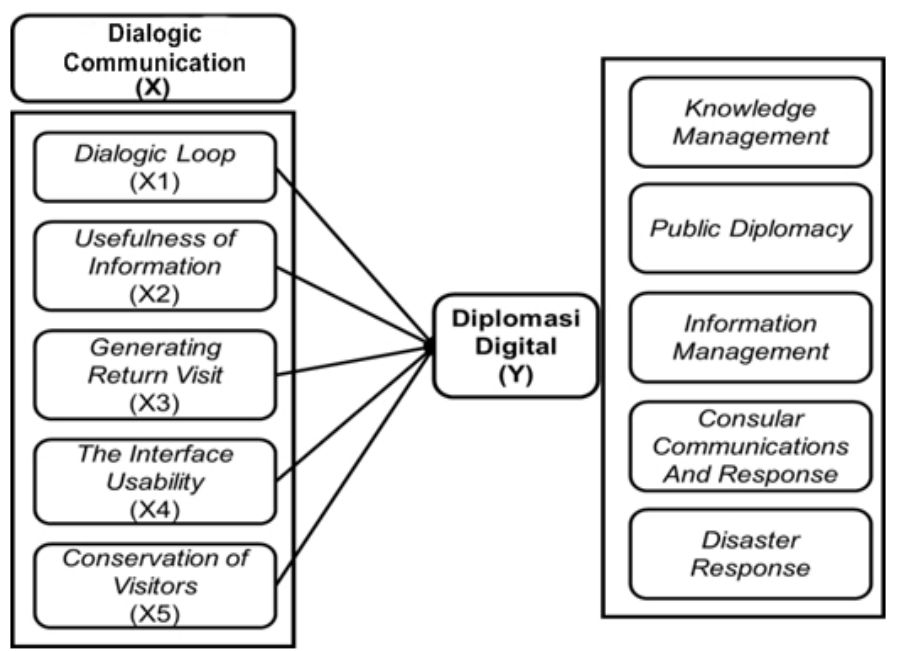

Figure 1 - Research Thinking Framework

The survey of dialogic communication (the independent variable) contained five dimensions divided into eleven indicators/ statements. The five dimensions were dialogic loops (X1), the usefulness of information (X2), generation of return visits (X3), the interface usability (X4), and conservation of visitors (X5).

On another side, the survey of digital diplomacy (the dependent variable) was taken from the concept of Hanson (2012, in Adesina, 2017: 3). Although Hanson (2012) explained eight objectives of digital diplomacy, this research only used five dimensions divided into thirteen indicators/ statements. The five dimensions of digital diplomacy (Y) were knowledge management, public diplomacy, information management, consular communications and response, and disaster response.

The data in this research were analyzed using a multiple linear regression. According to Sugiyono (2014: 299), multiple linear regression is a data analysis technique intended to predict the dependent variable state when it is influenced by two or more independent variables as the predictor factor. The equation of multiple linear regression analysis is formulated as follows: 


$$
Y=\alpha+b_{1} X_{1}+b_{2} X_{2}+b_{3} X_{3}+b_{4} X_{4}+b_{5} X_{5}
$$

Where:

$$
\begin{array}{rll}
\mathrm{Y} & = & \text { Dependent variable (digital diplomacy) } \\
\mathrm{A} & =\text { Constanta } \\
\mathrm{X} 1 & = & \text { Independent variable } 1 \text { (dialogic loop) } \\
\mathrm{X} 2 & = & \text { Independent variable } 2 \text { (usefulness of information) } \\
\mathrm{X} 3 & = & \text { Independent variable } 3 \text { (generation of return visits) } \\
\mathrm{X} 4 & = & \text { Independent variable } 4 \text { (the interface usability) } \\
\mathrm{X} 5 & = & \text { Independent variable } 5 \text { (conservation of visitors) } \\
\mathrm{b} 1-\mathrm{b} 5 & = & \text { Regression coefficient }
\end{array}
$$

\section{RESULTS AND DISCUSSION}

Validity Test Results. The sampling for the validity and reliability tests involved 42 respondents. The validity test was analyzed using SPSS software to process the data collected. By referring to the interpretation of Corrected Item-Total Correlation value, statement items will be considered valid if the validity coefficient is $>0.20$. In other words, the statement items can be said useful in showing the right measurement results.

The validity test results obtained from the 42 questionnaires showed that all the 24 statement items were valid because the Corrected Item-Total Correlation value was more than 0.20 .

Table 1 - Validity Test Results

\begin{tabular}{|c|c|c|c|}
\hline Item & Corrected Item-Total Correlation & Item & Corrected Item-Total Correlation \\
\hline XA1 & .432 & YA1 & .516 \\
\hline XA2 & .452 & YA2 & .561 \\
\hline XB1 & .512 & YA3 & .625 \\
\hline XB2 & .577 & YB1 & .333 \\
\hline XB3 & .612 & YB2 & .328 \\
\hline XC1 & .555 & YB3 & .516 \\
\hline XC2 & .616 & YC1 & .535 \\
\hline XC3 & .365 & YC2 & .498 \\
\hline XD1 & .565 & YC3 & .588 \\
\hline XD2 & .507 & YD1 & .334 \\
\hline XE1 & .341 & YE1 & .393 \\
\hline XE2 & .395 & YE2 & .429 \\
\hline
\end{tabular}

Reliability Test Results. As explained previously, the reliability test of this research involved 42 respondents. This test was conducted using Cronbach's Alpha. Cronbach Alpha is a measure of reliability that has values ranging from zero to one (Hair et al., 2010: 92). If the reliability value is $>0.40$, it can be concluded that the questionnaire can be relied upon as a data measuring instrument.

Table 2 - Reliability Test Results

\begin{tabular}{|c|c|}
\hline \multicolumn{2}{|c|}{ Reliability Statistics } \\
\hline Cronbach's Alpha & N of Items \\
\hline, 814 & 24 \\
\hline
\end{tabular}

The SPSS results suggested that the Cronbach's Alpha value of the 24 statement items reached 0.814 , greater than 0.40 . Thus, the questionnaire was said reliable.

Respondents Characteristic Results. Of the 42 questionnaires collected, it was found that the respondents were dominantly at the age range of 15 to 20 years, with a percentage of $90.5 \%$. Subsequently, the second order was occupied with those whose age was at the range of 21 to 30 years. The students majoring in the Communication Program Study Batch 
2016 of Bakrie University were still at young ages because most of them were just finished high school in 2016. They were mostly born from 1997 to 1998.

Viewed from the sex, the majority of the respondents who filled out the questionnaires were women $(52.4 \%)$ while the rest was men $(47.8 \%)$.

Lastly, the most underlying motive for the students of the Communication Program Study Batch 2016 of Bakrie University to travel abroad was for holidays (61.9\%), followed by the motive of education ( $26.2 \%$ ). That is, the trend to travel abroad was mostly driven by the need for recreation.

Table 3 - Respondent Characteristics

\begin{tabular}{|c|c|c|c|}
\hline \multirow{2}{*}{ No } & \multirow{2}{*}{ Characteristics } & \multicolumn{2}{|c|}{ Respondent Frequency } \\
\hline & & Number (N) & Percentage (\%) \\
\hline \multirow[t]{4}{*}{1} & \multicolumn{3}{|l|}{ Age } \\
\hline & $15-20$ years & 38 & $90.5 \%$ \\
\hline & $21-30$ years & 4 & $9.5 \%$ \\
\hline & $31-40$ years & 0 & $0 \%$ \\
\hline \multirow[t]{3}{*}{2} & \multicolumn{3}{|l|}{ Sex } \\
\hline & Male & 20 & $47.8 \%$ \\
\hline & Female & 22 & $52.4 \%$ \\
\hline \multirow[t]{6}{*}{3} & \multicolumn{3}{|c|}{ Travel Purpose (Motive) } \\
\hline & Education & 11 & $26.2 \%$ \\
\hline & Holiday & 26 & $61.9 \%$ \\
\hline & Working & 0 & $0 \%$ \\
\hline & Settling abroad & 4 & $9.5 \%$ \\
\hline & Others & 1 & $2.4 \%$ \\
\hline
\end{tabular}

Results of Respondent Knowledge About Safe Travel Application. Table 4 shows the extent to which the respondents knew about Safe Travel application. Seen from the questionnaire results, $54.8 \%$ of the respondents knew the function of Safe Travel application as a protective media for Indonesian citizens in foreign countries. Meanwhile, the other $33.3 \%$ of the respondents understood the function of Safe Travel application as an information media for Indonesian citizens travelling abroad.

Meanwhile, to find out about the presence of Safe Travel application, $71.4 \%$ of the respondents received information from different sources. The other $26.2 \%$ of the respondents knew the information about Safe Travel application from media and the remaining $2.4 \%$ knew it from the official website of KEMLU RI.

Table 4 - Respondent Knowledge About Safe Travel Application

\begin{tabular}{|c|c|c|c|}
\hline \multirow{2}{*}{ No } & \multirow{2}{*}{ Indicator } & \multicolumn{2}{|c|}{ Frequency of Respondents } \\
\hline & & Number $(\mathrm{N})$ & Percentage (\%) \\
\hline \multirow[t]{5}{*}{1} & \multicolumn{3}{|l|}{ Application Functions } \\
\hline & Protecting Indonesian citizens abroad & 23 & $54.8 \%$ \\
\hline & As information media for Indonesian citizens abroad & 13 & $33.3 \%$ \\
\hline & $\begin{array}{l}\text { Facilitating Indonesian citizens to contact and get the location of important } \\
\text { Indonesian parties abroad }\end{array}$ & 2 & $4.8 \%$ \\
\hline & Others & 3 & $7.1 \%$ \\
\hline \multirow[t]{5}{*}{2} & \multicolumn{3}{|l|}{ Sources of Information About Safe Travel Application } \\
\hline & Media coverage & 11 & $26.2 \%$ \\
\hline & KEMLU RI website & 1 & $2.4 \%$ \\
\hline & KEMLU RI activities & 0 & $0 \%$ \\
\hline & Others & 30 & $71.4 \%$ \\
\hline \multirow[t]{6}{*}{3} & \multicolumn{3}{|l|}{ The duration of Safe Travel Application Usage } \\
\hline & $<1$ Week & 38 & $90.5 \%$ \\
\hline & $1-4$ Weeks & 2 & $4.8 \%$ \\
\hline & $1-2$ Months & 0 & $0 \%$ \\
\hline & $3-4$ Months & 2 & $4.8 \%$ \\
\hline & $4-6$ Months & 0 & $0 \%$ \\
\hline
\end{tabular}


Furthermore, if seen from the duration of Safe Travel application usage, $90.5 \%$ of the respondents recognized that they had less than a week in using the application. As for the rest, each $4.8 \%$ of the respondents had used the application for 1-4 weeks and 3-4 months.

Results of Identifying Dialogic Communication Dimensions Affecting Digital Diplomacy. The multiple regression analysis was carried out to identify the significant effect of dialogic communication dimensions on digital diplomacy conducted by the Ministry of Foreign Affairs of the Republic of Indonesia (KEMLU RI). The results of the analysis using SPSS are as follows:

Seen in Table 5, the R-value obtained was equal to 0.699 and the $\mathrm{R}$ Square was equal to 0.489 . This indicates that the independent variables (dialogic communication dimensions) had a correlation of $69.9 \%$ with the dependent variable (digital diplomacy) or was said to be weak because the number of R obtained was 0.699 (below 1). Meanwhile, the determinant coefficient value (R Square) of 0.489 indicates that $48.9 \%$ of the variance of digital diplomacy could be explained by dialogic communication dimensions and the other $51.1 \%$ was explained by other variables.

Table 5 - Model Summary

Model Summary

\begin{tabular}{|l|r|r|r|r|}
\hline Model & $\mathrm{R}$ & $\mathrm{R}$ Square & Adjusted R Square & $\begin{array}{c}\text { Std. Error of the } \\
\text { Estimate }\end{array}$ \\
\hline 1 &, $699^{\mathrm{a}}$ &, 489 &, 418 & 2,85430 \\
\hline
\end{tabular}

a. Predictors: (Constant), X1, X2, X3, X4, X5

Table 6 - F Test Result

\begin{tabular}{|rl|r|r|r|r|r|}
\hline \multicolumn{1}{|c|}{ ANOVA $^{\mathrm{a}}$} & \multicolumn{1}{c|}{ Sig. } \\
\hline \multirow{2}{*}{1} & Sum of Squares & df & Mean Square & F &, $000^{\mathrm{b}}$ \\
& Regression & 280,539 & 5 & 56,108 & 6,887 & \\
& Residual & 293,294 & 36 & 8,147 & & \\
& Total & 573,833 & 41 & & & \\
\hline
\end{tabular}

a. Dependent Variable: $Y$

b. Predictors: (Constant), X1, X2, X3, X4, X5

Table 7 - Multiple Linear Regression Coefficients of Dialogic Communication Dimensions on Digital Diplomacy

Coefficients $^{\mathrm{a}}$

\begin{tabular}{|c|c|c|c|c|c|c|}
\hline \multirow{2}{*}{\multicolumn{2}{|c|}{ Model }} & \multicolumn{2}{|c|}{ Unstandardized Coefficients } & \multirow{2}{*}{$\begin{array}{c}\text { Standardized } \\
\text { Coefficients } \\
\text { Beta }\end{array}$} & \multirow[t]{2}{*}{$\mathrm{t}$} & \multirow[t]{2}{*}{ Sig. } \\
\hline & & B & Std. Error & & & \\
\hline \multirow{6}{*}{1} & (Constant) & 20,886 & 6,396 & & 3,265 & ,002 \\
\hline & $\mathrm{X} 1$ & ,972 & ,455 & ,265 & 2,138 & ,039 \\
\hline & $X 2$ & ,693 & ,392 & ,242 & 1,766 & ,086 \\
\hline & X3 & 1,188 & ,367 & ,439 & 3,233 & ,003 \\
\hline & $X 4$ & ,251 & ,499 & ,068 &, 504 & ,617 \\
\hline & $\times 5$ &,- 574 & ,582 &,- 125 &,- 987 & ,330 \\
\hline
\end{tabular}

a. Dependent Variable: $Y$ 
By using the F-test results, the researchers tried to see the effect of the independent variables (dialogic communication dimensions) on the dependent variable (digital diplomacy) simultaneously. Table 6 shows that the significance value was less than $\alpha(0.05)$. That is, the independent variables (dialogic communication dimensions) simultaneously had an effect on the dependent variable (digital diplomacy) and could be used to predict digital diplomacy.

Based on the results presented in Table 7 , only X1 and X3 had smaller significance values than 0.05 , respectively reaching 0.039 and 0.003 . This indicates that dialogic loops and generation of return visits had a significant effect on digital diplomacy.

Meanwhile, the variables $\mathrm{X} 2, \mathrm{X} 4$, and $\mathrm{X} 5$ obtained significance values of respectively $0.086,0.617$, and 0.330 (greater than 0.05 ). In other words, the usefulness of information, the interface usability and conservation of visitors did not significantly affect digital diplomacy.

If the numbers are included in the equation, the results will be as follows:

$$
\begin{gathered}
Y=\alpha+b_{1} X_{1}+b_{2} X_{2}+b_{3} X_{3}+b_{4} X_{4}+b_{5} X_{5} \\
Y=20,886+(0,972) X_{1}+(0,693) X_{2}+(1,188) X_{3}+(0,251) X_{4}+(-0,547) X_{5}
\end{gathered}
$$

That is, if the impact of dialogic loop and generation of return visits is better perceived, it will increase digital diplomacy conducted by KEMLU RI. However, generation of return visits can provide higher thrust to digital diplomacy because its coefficient had a value of 1.118 , greater than the dialogic loop whose coefficient value was 0.972 .

Based on the above findings, the results of the statistical hypothesis testing can be described as follows,

- Dialogic loop had a positive effect on digital diplomacy, meaning that $\mathrm{H} 1(\mathrm{X} 1 \rightarrow \mathrm{Y})$ was accepted.

- Usefulness of information had no effect on yet had a positive relationship to digital diplomacy, meaning that $\mathrm{H} 2(\mathrm{X} 2 \rightarrow \mathrm{Y})$ was rejected.

- Generation of return visits had a positive effect on digital diplomacy, meaning that $\mathrm{H} 3$ $(\mathrm{X} 3 \rightarrow \mathrm{Y})$ was accepted.

- The interface usability had no effect on yet had a positive relationship to digital diplomacy, meaning that $\mathrm{H} 4(\mathrm{X} 4 \rightarrow \mathrm{Y})$ was rejected.

- Conservation of visitors had no effect on and negative relationship to digital diplomacy, meaning that $\mathrm{H} 5(\mathrm{X} 5 \rightarrow \mathrm{Y})$ was rejected.

\section{DISCUSSION OF RESULTS}

Overall, the dimensions of dialogic communication are considered capable of predicting digital diplomacy conducted by KEMLU RI. However, of the five dimensions, only two dimensions (dialogic loop and generation of return visits) had a positive effect on digital diplomacy.

The Effect of Digital Loop on Digital Diplomacy. The results of the multiple linear regression analysis showed that dialogic loops had a positive effect on digital diplomacy.

Dialogic loop focuses on the public opportunity to ask questions to organizations; and organizations have the opportunity to respond to them (Kent and Taylor, 1998, in Kampf, Manor, Segev, 2015).

The implementation of dialogic loops in Safe Travel application is applied to the Emergency Button feature. The Emergency Button is a feature used in an emergency. Indonesian citizens abroad can use the Emergency Button feature to send photos, record videos, contact the nearest Indonesian Representative and send important scenes (www.kemlu.go.ig, accessed on August 15, 2018). Through this feature, it is very possible for the users to make contact with KEMLU RI to get the answers or information needed.

Meanwhile, in digital diplomacy, there are dimensions of public diplomacy, consular communication and response, and disaster response. 
Public diplomacy is the act of making contact with audiences when they migrate online by utilizing new communication tools to listen to and target important audiences to deliver messages and affect influencers online (Hanson, 2012, in Adesina, 2017: 3).

Moreover, the implementation of digital loops in Safe Travel application is considered successful in conveying the principles of public diplomacy, consular communication and response, and disaster response (three of digital diplomacy dimensions). Through the Emergency Button feature, the users can make contact with KEMLU RI. From these interactions, KEMLU RI can target its goals and deliver messages to Indonesian citizens abroad.

Consular communication and response are activities to create a direct communication channel with citizens travelling abroad in which the communication can be managed in critical situations (Hanson, 2012, in Adesina, 2017: 3). On another side, disaster response is an activity to utilize the power of communication technology in responding to a disaster (Hanson, 2012, in Adesina, 2017: 3).

According to its name, the Emergency Button feature can be utilized by the users to report important events, either emergency situations or disasters, experienced during their overseas trips in the form of photos or videos.

However, even though it has been equipped with a digital loop feature, Safe Travel application practically tends not to be used by Indonesian Migrant Workers (TKI). The results of interviews conducted with several Indonesian Migrant Workers in Singapore, namely Novia, Rina Saldiah, and Farida showed that they did not have to bother themselves to make contact with KEMLU RI or the government in Singapore. They just relied on their friendship bond in the community of fellow Indonesian Migrant Workers in Singapore to overcome the problems faced. They also got support from their employers and distributing agents.

The Effect of Generation of return visits on Digital Diplomacy. The results of the multiple linear regression analysis showed that the generation of return visits had a positive effect on digital diplomacy.

Generation of return visits focuses on continually updating information, adjusting information to public needs, and holding a Q\&A forum with experts (Kent and Taylor, 1998, in Kampf, Manor, Segev, 2015).

The implementation of generation of return visits in Safe Travel application is applied in the features of Complete Information on World Countries and Indonesia Nearby.

The feature of Complete Information on World Countries contains the country status, access to RI Representative services, list of 130 RI Representatives, local laws and customs, currency, tourism and worship objects, halal culinary, and infographics (www.kemlu.go.id, accessed on August 15, 2018). Through this feature, the users can always update the information needed.

Indonesia Nearby is a feature providing information about other Indonesia citizens nearby the user's location when travelling abroad. With this feature, Indonesian citizens can each other get acquainted, chat and develop a network of friends to strengthen the community of Indonesian citizens abroad (www.kemlu.go.id, accessed on August 15, 2018). This feature can be the beginning of the emergence of a Q\&A forum between fellow users in which information exchange occurs.

Meanwhile, in digital diplomacy, there are knowledge management and information management dimensions.

Knowledge management is utilizing the knowledge of a department and government so as to be maintained, shared and used optimally to pursue national interests abroad (Hanson, 2012, in Adesina, 2017: 3).

The implementation of generation of return visits in Safe Travel application is considered successful in channelling knowledge management functions in digital diplomacy. This is applied to the feature of Complete Information on World Countries in which the users can access the database of KEMLU RI's knowledge as information needed when travelling abroad. 
Information management is the collection of information flows to help policy making as well as anticipate and respond to emerging social and political movements (Hanson, 2012, in Adesina, 2017: 3).

As for the information management dimension, the implementation of generation of return visits in Safe Travel application is presented in Indonesia Nearby feature. Through this feature, Indonesian citizens travelling abroad can gather or form forums both offline and online in which their proposals or voices can contribute to the betterment of Indonesia foreign policies.

Table 8 - Social Media of KEMLU RI

\begin{tabular}{|l|l|}
\hline Twitter & $\begin{array}{l}\text { The content is more about policies and substance of information delivered in formal language as the } \\
\text { audiences are more critical over these. The use of Twitter has both positive and negative responses } \\
\text { from the informants. }\end{array}$ \\
\hline Facebook & $\begin{array}{l}\text { The content tends to be lighter (tourism, culinary, etc.) and presents more photos or infographics. } \\
\text { The use of Facebook tends to get a positive response from the informants. }\end{array}$ \\
\hline Youtube & $\begin{array}{l}\text { The content contains video cut-offs of the activities and press conference of the Minister or KEMLU. } \\
\text { The use of youtube tends to get a positive response from the informants. }\end{array}$ \\
\hline Instagram & $\begin{array}{l}\text { The content tends to be lighter (tourism, information on student exchange learning, country } \\
\text { knowledge, culinary, etc.). Message delivery is dominantly visual such as activity photos, posters, } \\
\text { videos, and infographics. This content targets millennial youth. The use of Instagram gets a positive } \\
\text { response from the informants. }\end{array}$ \\
\hline
\end{tabular}

However, the implementation of generation of return visits is biased because KEMLU $R I$ does not focus only on Safe Travel application as a protective media for Indonesian citizens abroad. According to the results of the interview with Aji Nasution, the Head of the Subdirectorate for Media, KEMLU RI does not only focus on Safe Travel application but also utilize social media such as Twitter, Facebook, Youtube, and Instagram.

Aji also stated that each of the social media has a different perspective and language style despite similar disseminated information. The following is the role mapping of each social media used by KEMLU RI (according to Aji) as mentioned in Table 8 above.

The Effect of Usefulness of information on Digital Diplomacy. Based on the multiple linear regression analysis results, usefulness of information had no effect yet was positively related to digital diplomacy.

Usefulness information is information derived from sources that are reliable, useful and relevant to the public (Kent and Taylor, 1998, in Kampf, Manor, Segev, 2015).

In the researchers' perspectives, the effect of usefulness of information was invisible because $90.5 \%$ of the respondents recognized that they had only less than a week in using Safe Travel application. As a result, they could not experience the actual function of Safe Travel application and skipped information provided by $K E M L U R I$ in the application as a trusted source.

This indicates that the publication of the introduction of Safe Travel application conducted by KEMLU RI is not on target.

As stated by Aji Nasution in the interview, KEMLU RI has run various socializations to introduce Safe Travel application to the public, including:

- The launch in the form of an event which was only done once at Grand Central Mall West Jakarta.

- Talk shows on BRAVA Jakarta radio.

- Introduction through KEMLU RI social media

The impact of the socialization that has been explained by $K E M L U R I$ is considered not to reach the public who should be the target users of Safe Travel application. This is shown by the facts that:

- $71.4 \%$ of the respondents obtained the information of the presence of Safe Travel application from various sources. That is, the respondents knew directly the application neither from the activities nor the communication line of KEMLU RI. In other words, the socialization conducted by KEMLU RI about Safe Travel application has no effect. 
- Other target users of Safe Travel application should be Indonesian Migrant Workers $(T K I)$. However, the results of the interviews with several TKIs in two different countries showed that they neither use nor even know Safe Travel application.

Novia, Rina Saldiah and Farida, Indonesian Migrant Workers in Singapore, explained that when they had problems in the country, they usually asked for help to their friends in the community of fellow Indonesian Migrant Workers in Singapore or to their employers and agents who distributed them.

Similarly, Siti Nurbayati, Solehah, and Rismayanti, Indonesian Migrant Workers in Taiwan, recognized that they did not know about the launch of Safe Travel application by $K E M L U R I$, so they never used it. Thus, whenever they were in trouble, they only could share it and ask for help to their community.

The Effect of the interface usability on Digital Diplomacy. The results of the multiple linear regression analysis showed that the interface usability had no effect yet was positively related to digital diplomacy.

The interface usability is an easier and more textual navigation than online graphics contents (Kent and Taylor, 1998, in Kampf, Manor, Segev, 2015).

Similar to usefulness of information, the function of the interface usability dimension could not be experienced by the respondents due to the short duration of the application usage. $90.5 \%$ of the respondents stated that they had just downloaded Safe Travel application for less than a week. This again shows the lack of impact of the socialization that has been carried out by the Ministry of Foreign Affairs of the Republic of Indonesia.

The Effect of Conservation of visitors on Digital Diplomacy. Viewed from the multiple linear regression analysis results, the dimension of conservation of visitors had no effect and led to a negative value on digital diplomacy.

Conservation of visitors is an activity to avoid publications encouraging the public not to give feedback or make another visit (Kent and Taylor, 1998, in Kampf, Manor, Segev, 2015).

The implementation of conservation of visitors in Safe Travel application has no effect even potentially decreases digital diplomacy. The researchers consider that this can occur due to several factors as follows:

- No control over what information is available and what the information form is like in Safe Travel application. This is supported by the opinion of Aji Nasution, the Head of the Subdirectorate for Media stating that Safe Travel application is still in the development stage.

- Minimum respondent involvement, viewed from the short duration of the application usage and the application introduction sources which are mostly not from KEMLU RI socializations.

\section{CONCLUSION}

Based on the results of the multiple linear regression analysis, only two of five dialogic communication dimensions positively affects digital diplomacy, namely digital loop and generation of return visits. Compared to dialogic loops, generation of return visits can provide more thrust to digital diplomacy, indicated by its greater coefficient. Meanwhile, usefulness of information, the interface usability, and conservation of visitors have no effect on digital diplomacy. Among the dimensions that have no effect, only conservation of visitors has a negative relationship with digital diplomacy.

There is a difference in understanding communication strategies of Safe Travel application between KEMLU RI and the target public. According to KEMLU RI, Safe Travel application has been successfully launched with the support of some socialization as a medium for introducing Safe Travel application.

In contrast, according to the reality in the field, two of the target users of Safe Travel application indicate that the socialization does not impact the communication strategies or introduction of Safe Travel application to the public.

Moreover, students majoring in the Communication Study Program of Bakrie University who fall within Generation $Z$ as one of the target users of Safe Travel application are 
considered to newly know about the application. The respondents of this research did not get the information of the application launch or introduction directly from the KEMLU RI communication line.

Additionally, the other target users of Safe Travel application are Indonesian Migrant Workers $(T K I)$. This research involved Indonesian Migrant Workers in two countries (Taiwan and Singapura). However, according to their recognition, most of them neither know nor even use Safe Travel application. They tend to rely on community functions, channelling agents, and their employers as their supporting systems when they face problems while working abroad.

Optimization of KEMLU RI in each of its timelines is still insufficient so as to cause a bias where there is no integration between online and offline communication strategies that should not only be socialized domestically but also globally.

In this regard, KEMLU RI is expected to reconduct analysis of the target mapping of Safe Travel application and rearrange the appropriate communication strategies used for each target user of the application. Digital platform management (Twitter, Facebook, Youtube, Instagram and Safe Travel application) must continue to be developed in terms of contents according to the characteristics of each social media and its target users.

\section{REFERENCES}

1. Adam, Aulia. (28 April 2017). Selamat Tinggal Generasi Milenial, Selamat Datang Generasi Z. https://tirto.id/selamat-tinggal-generasi-milenial-selamat-datang-generasi-zcnzX, diakses 9 September 2018.

2. Adesina, Olubukola S. (2017). Foreign Policy in An Era of Digital Diplomacy. Cogent Social Sciences, 3, $1-13$.

3. Adiakurnia, Muhammad Irzal. (10 Januari 2018). Tahun 2018, Semakin Banyak Turis Indonesia Liburan ke Luar Negeri, https://travel.kompas.com/read/2018/01/10/090000527/tahun-2018-semakin-banyakturis-indonesia-liburan-ke-luar-negeri, diakses 14 Agustus 2018.

4. Agozzino, Alisa. (2015). Dialogic Communication Through "Pinning": An Analysis of Top 10 Most-Followed Organizations' Pinterest Profiles. Public Relations Journal, 9(3), 1 13.

5. Anderson, Betsy D., Rebecca Swenson dan Nathan D. Gilkerson. (2016). Understanding Dialogue and Engagement Through Communication Experts' Use of Interactive Writing to Build Relationships. International Journal of Communication, 10, 4095 - 4118.

6. Creswell, John W. (2008). Research Design, Pendekatan Kualitatif, Kuantitatif, dan Mixed, Edisi Ketiga. Badung: Pustaka Pelajar.

7. Effendy, Onong Uchjana. (2013). Ilmu Komunikasi Teori dan Praktek. Bandung: PT Remaja Rosdakarya.

8. Hair, Joseph F. (2010). Multivariate Data Analysis. 7th Edition. New York: Prentice Hall International, Inc.

9. Hancock, Beverley, Elizabeth Ockleford dan Kate W. (2009). An IntOroduction to Qualitative Research. Nottingham: The NIHR RDS for the East Midlands.

10. Hesse-Biber, Sharlene Nagy, dan Patricia L. L. (2011). The Practice of Qualitative Research. $2^{\text {nd }}$ Edition. United States of America: SAGE Publication, Inc.

11. Kampf, Ronit. Ilan Manor, and Elad S. (2015). Digital Diplomacy 2.0? A Cross-National Comparison of Public Engagement in Facebook and Twitter. Hague Journal of Diplomacy, 10(4).

12. Kementrian Luar Negeri Republik Indonesia. (6 April 2018). Bepergian yang Aman dan Menyenangkan bersama Safe Travel Kemlu. https://www.kemlu.go.id/, diakses 15 Agustus 2018.

13. Lestari, Sri Handi. (10 Agustus 2018). Penetrasi Pengguna Internet Tahun 2018 Diprediksi Tumbuh Hingga 60 Persen. http://surabaya.tribunnews.com/, diakses 14 Agustus 2018. 
14. Lister, Martin, Jon Dovey, Seth Giddings dan Kieran Kelly. (2009). New Media: A Critical Introduction. New York: Routledge.

15. Maya, Sophie. Generasi Millennial, Kalianlah Penguasa Dunia Traveling Saat Ini. https://phinemo.com/generasi-Milenial-indonesia/, diakses 11 September 2018.

16. McAllister-Spooner, Sheila M. (2008). User Perceptions of Dialogic Public Relations Tactics via the Internet. Public Relations Journal, 2(1), $1-18$.

17. McQuail, Denis. (2011). Teori Komunikasi Massa McQuail, Edisi 6 Buku 1. Jakarta: Salemba Humanika.

18. Perhimpunan Pelajar Indonesia. (10 Desember 2017). Skeptis pada Media Sosial, Tantangan bagi Generasi Milenial. Skeptis pada Media Sosial, Tantangan bagi Generasi Milenial. https://nasional.kompas.com/read/2017/12/10/10283451/skeptis-pada-mediasosial-tantangan-bagi-generasi-milenial?page=all., diakses 11 September 2018.

19. Ruben, Brent D. dan Lea P. S. (2006). Communication and Human Behavior. $5^{\text {th }}$ Edition. United States of America: PearsonEducation, Inc.

20. Sanusi, Anwar. (2011). Metodologi Penelitian Bisnis. Jakarta: Penerbit Salemba Empat.

21. Seib, Philip. (2009). Public Diplomacy and Journalism: Parallels, Ethical Issues, and Practical Concerns. SAGE Publication, 52 (5), 772 - 786.

22. Siregar, Chairil Anhar. (5 Maret 2018). Aman Berpergian ke Luar Negeri dengan Safe Travel. https://kumparan.com/chairil-anhar-siregar1519198977416/aman-berpergian-keluar-negeri-dengan-safe-travel, diakses 9 September 2018.

23. Sugiyono. (2014). Metode Penelitian Kuantitatif, Kualitatif, dan R\&D. Bandung: Penerbit Alfabeta.

24. Winastiti, Agnes. (28 Agustus 2016). Generasi Millenial dan Karakteristiknya. https://student.cnnindonesia.com/edukasi/20160823145217-445-153268/generasimillenial-dan-karakteristiknya/, diakses 11 September 2018.

25. Wood, Julia T. (2011). Communication Mosaic: An Introduction to the Field of Communication. International Edition. England: Wadsworth Cengage Learning.

26. Zhang, Juyan. (2013). A Strategic Issue Management (SIM) Approach to Social Media Use in Public Diplomacy. SAGE Publications.,57(9), 1312-1331 